\title{
Editorial
}

\section{University Staff and Student Protection from COVID-19: Strategic Measures for Teaching and Learning in Resource-limited Setting}

Mohamed A. M. Ibnouf, FRCSEd, PhD

Publons web of science researcher ID: C-4902-2009

ORCID:

Mohamed A. M. Ibnouf: https://orcid.org/0000-0001-8231-9899

Corresponding Author: Mohamed A. M. Ibnouf; email: maibnouf@gmail.com

Received 20 March 2021 Accepted 26 March 2021 Published 31 March 2021

Production and Hosting by Knowledge E

(c) Mohamed A. M.

Ibnouf. This article is

distributed under the terms of the Creative Commons

Attribution License, which permits unrestricted use and redistribution provided that the original author and source are credited.

Editor-in-Chief:

Prof. Mohammad A. M. Ibnouf
So far, COVID-19 has claimed millions of lives $[1,2]$. This editorial in Sudan Journal of Medical Science reflects the strategic measures designed for teaching and learning in Omdurman Islamic University (OIU) as an example of a high educational institute in a low-income country to protect the staff and students during the pandemic. However, the published protocols and guidelines may prove inadequate for combating the disastrous effects of the fast-spreading new strains of the virus [3].

In addition to high mortalities during the first wave of COVID-19 in Sudan, in MarchJune 2020, government universities faced extraordinary challenges in introducing elearning in their curricula. This situation was worsened by the unprecedented inflation in economy, repeated electricity cut-offs, and low-frequency Internet flow.

Several published studies have explored the impact of COVID-19 on university education, as well as experiences in e-learning during the pandemic. We searched databases such as PubMed, Medline, Google, as well as the local social media for relevant data published between December 1, 2019 and March 12, 2021. According to the published reports, COVID-19 mortalities rose faster among college communities than in the rest of the population. Moreover, since the onset of the pandemic, a Times's survey has identified 397,000 infections at more than 1,800 colleges and universities in the US. The cases included $>90$ deaths of college employees and students [4]. Also, 20 staff members and 2 students from universities across South Africa were reported to have died of coronavirus [5]. About 109 deaths occurred among Sudanese medical doctors and 7 university staff members between January 14, 2020 and March 12, 2021.

We noticed that adherence to COVID-19 prevention measures among the staff and students were not optimal, despite the fact that transmission is lower with physical distancing $\geq 1 \mathrm{~m}$ than $<1 \mathrm{~m}$ and face mask (particularly N95) reduces significantly the infection rate [6]. 
During the pandemic, transition to e-learning was considered the best alternative. During the short advocacy period, the voice of the opponents and the resistant staff was rather high. Challengers spoke about the unfamiliarity with e- learning, poor facilities for staff and students, instability of electricity, etc. Hence, to evaluate the training needs of the OIU staff, a validated, pretested self-administered questionnaire was sent as a Google form to 1,500 OIU staff members. Separately, two other validated, pretested self-administered questionnaires were sent as Google forms to the teaching staff members of the Faculty of Medicine and to the medical students. Data were analyzed automatically by Google.

The retrieval rate of the questionnaire sent to the members of the university teaching staff was 740 (49.3\%). Of these responders, 358 (48.4\%) were capable of using computer for preparing their lectures. Also, 713 (96.8\%) had access to smart phones and computers with Internet facilities and 643 (86.9\%) used e-mails and social media programs. However, only 295 (39.8\%) responders used electronic media to send assignments and receive responses from their students. About 510 (69\%) OIU staff members had variable experiences in using computers such as preparing a PDF file, but only $9.9 \%$ had experience with a learning management program, particularly Moodle.

The university information technology (IT) center added a bandwidth of $158 \mathrm{Mbps}$ to broaden and fasten the university Internet speed. The university website was upgraded to upload all timetables and archives of the educational modules. Training in utilizing Moodle to ensure an effective e-learning delivery was given. Moodle was chosen because it is a free learning management system (LMS) source to augment and move the existing learning environment online.

At the time of writing this editorial, several courses in 5 of the 21 university faculties were started as blended modules. The students show up for face-to-face training only at the end of the semester. The exam results revealed good student attainments. However, in the remaining 16 faculties, routine classical teaching has been resumed.

The compliance of the students and adherence to the preventive measures was rather low. The anticipated fast-spreading strains of the virus dictated enhancing training for the rest of the faculties. However, one of the major obstacles is the financial constraints and resistance of few senior teaching staff members. The resistant staff and those who have technophobia [7-9] will be assigned for face-to-face training of the students and to take the responsibility of some administrative jobs.

Because this was a preliminary exploratory survey to assess the training needs of university students and staff, we accepted the small sample size to fasten the e-learning program. Face-to-face interaction during teaching and learning is the classical method 
that builds confidence between the educator and students. However, in the COVID-19 pandemic, universities are working hard to endure the change in a new norm.

The fast-developing technologies have improved distance communication, teleconferencing, and virtual classrooms to access teaching and training from worldwide sources. As the pandemic has hit hard the global economy and claimed millions of lives, transnational collaboration and nongovernmental support spark to give hope to overcome the challenges. However, with the donors' fatigue, OIU struggles hard to train the staff and students to adopt a distant-learning strategy as an alternative to faceto-face teaching in crowded classrooms in a low-resource setting. All the given reasons along with the electricity cut-offs and unstable Internet bandwidth slowed the change and forced the OIU staff and students to incline toward asynchronous e-learning.

University staff and students were reported to develop high psychological distress that influences their presence and absence [10]. Nevertheless, e-learning is a great opportunity to enhance the university's effectiveness and efficiency, however, the needed infrastructure for e-learning might not be readily found in low- and middleincome countries (LMIC) [11].

In order to prevent further loss of precious lives, OIU is moving toward blended learning. This strategy safeguards asynchronous teaching in the theoretical part of the curricula augmented by social media and telecommunication between students and staff. Also, it guarantees physical distancing in small student groups during training at the end of each semester.

\section{References}

[1] Ramani, V. K., Shinduja, R., Suresh, K. P., et al. (2020). A study on the global scenario of COVID-19 related case fatality rate, recovery rate, and prevalence rate and its implications for India -a record-bases retrospective cohort study. Advances in Infectious Diseases Journal, vol. 10, pp. 233-248.

[2] Katherine, L. (2020). The link between humidity and COVID-19 caused death. Journal of Biosciences and Medicines, vol. 8, no. 6, pp. 50-55.

[3] Tomezuka, T., Kanatani, Y., and Kawahara, K. (2013). Insufficient preparedness of primary care practices for pandemic influenza and the effect of a preparedness plan in Japan: a prefecture-wide plan cross-sectional study. BMC Family Practice, vol. 14, p. 174.

[4] Ivory, D., Gebeloff, R., and Mervosh, S. Young People Have Less Covid-19 Risk, but in College Towns Deaths Rose Fast. The New York Times. March 2, 2021. 
[5] Macupe, B. South African universities record 22 deaths from Covid-19. The Mail \& Guardian. 2020, July 23.

[6] Chu, D. K., Aki, E. A., Duda, S., et al. (2020). Physical distancing, face mask and eye protection to prevent person-to-person transmission of SARS-CoV-2 and COVID-19: a systematic review and meta-analysis. Lancet, vol. 395, no. 10242, pp. 1973-1987.

[7] Rajab, N. H., Gazal, A. M., and Alkattan, K. (2020). Challenges to online medical education during the COVID-10 pandemic. Cureus, vol. 12, no. 7, e8966.

[8] Estrada-Munoz, C., Castillo, D., Vega-Munoz, A., et al. (2020). Teacher technostress in the Chilean school system. International Journal of Environmental Research and Public Health, vol. 17, no. 15, p. 5280.

[9] Pietrocola, M., Rodrigues, E., Bercot, F., et al. (2020). Risk society and science education: lessons from COVID-19 pandemic. Science Education, pp. 1-25. Retrieved from: https://rdcu.be/cgP7G

[10] Van Der Heltz-cornelis, C. M., Varley, D., Aligar, V. L., et al. (2020). Workplace stress, presenteeism, absenteeism and resilience amongst university staff and students in COVID-19 lockdown. Frontiers in Psychiatry, vol. 11, 588803.

[11] Frehywot, S., Vovides, Y., Talib, Z., et al. (2013). E-learning in medical education in resource constrained low- and middle-income countries. Health, vol. 4, no. 11, p. 4. 